\title{
Health benefits of dairy lipids and MFGM in infant formula
}

\author{
Isabelle Le Huërou-Luron *, Marion Lemaire and Sophie Blat \\ INRA, INSERM, Rennes Univ, Nutrition Metabolisms and Cancer (NuMeCan), Rennes, France
}

Received 28 February 2018 - Accepted 8 March 2018

\begin{abstract}
Human breast milk (HBM) is the gold standard for the early nutrition of the neonates. The best way to improve infant formulas (IFs) is to mimic both the composition and the structure of HBM components. Supplementation of IF with dairy lipids or bovine milk components such as milk fat globule membrane (MFGM), in partial replacement of plant oils that are currently mainly used, has health benefits for infants. In this article, results of clinical studies on the impact of IF supplementation with MFGM and dairy lipids on psychomotor development and infectious disease prevalence in infants are reviewed and supported by recent pre-clinical studies. Numerous human studies have reported beneficial effects of MFGM supplementation on neurocognitive development and protection against infectious agents without deleterious impact on growth. Based on rodent and porcine studies, benefits of adding bovine MFGM and dairy lipids in IFs on gut digestion, physiology and protection against pathogens and inflammatory challenges have also been highlighted. However, more randomized controlled trials testing IF supplementation with bovine milk fat, and specifically apolar lipids and associated glycoproteins, must be performed to increase scientific-based knowledge, address safety concerns, and study its potential programming role of adult health.
\end{abstract}

Keywords: bovine milk fat / polar lipid / milk composition / infant formula / infant health

\begin{abstract}
Résumé - Les bénéfices santé des lipides laitiers et des membranes des globules gras introduits dans les formules infantiles. Le lait maternel est l'aliment de choix à privilégier pour nourrir les nouveaunés. Il est ainsi l'aliment de référence tant sur sa composition nutritionnelle que sur ses propriétés fonctionnelles, pour améliorer la formulation des formules infantiles (FI). L'incorporation dans les FI de la matière grasse du lait de vache ou de certains de ses composants tels que les membranes des globules gras (MFGM pour milk fat globule membrane), en remplacement partiel des huiles végétales qui sont actuellement principalement utilisées, apporte des effets bénéfiques pour la santé du nouveau-né. Dans cette revue, les résultats des études cliniques sur l'impact des MFGM et des lipides laitiers dans les FI sur le développement psychomoteur et la prévalence des maladies infectieuses et digestives infantiles sont rapportés et étayés par les résultats d'études pré-cliniques récentes. L'incorporation de MFGM dans les FI apporte un bénéfice sur le développement neurocognitif de l'enfant et sa protection vis-à-vis d'agents infectieux, sans modifier sa croissance. L'effet bénéfique de la supplémentation des FI avec des lipides laitiers et des MFGM d'origine bovine sur la digestion et la physiologie intestinale, ainsi que la protection contre des challenges inflammatoires est par ailleurs mis en évidence dans des études pré-cliniques réalisées chez les rongeurs ou le porc. Cependant, de nouvelles études sont nécessaires pour accroître nos connaissances sur le rôle fonctionnel et le mode d'action de la matière grasse laitière et en particulier, des lipides apolaires et des glycoprotéines associées aux MFGM, et ses effets potentiels sur la programmation de la santé de l'adulte.
\end{abstract}

Mots clés : matière grasse laitière / lipide polaire / composition du lait / formule infantile / santé infantile

\footnotetext{
*Correspondence: INRA, NuMeCan, 16 Le Clos, 35590 Saint-Gilles,

France. isabelle.luron@inra.fr
} 


\section{Introduction}

Human breast milk (HBM) from healthy mothers is a timely-adapted and balanced source of nutrients and bioactive compounds ensuring proper growth and development of infants, and is therefore the gold standard for early nutrition of full-term infants up to six months of age. Hence, the best way to improve infant formulas (IFs) is to mimic both the composition and the structure of HBM components. A range of values for macronutrient contents in IFs is now well defined. An ideal protein content of $1.8 \mathrm{~g} / 100 \mathrm{kcal}$, very close to HBM (Tab. 1), is established for bovine milk protein-based IFs on the basis of reducing the risk for rapid weight gain during infancy, a known-risk factor for overweight and obesity up to school age (Koletzko et al., 2009; Weber et al., 2014). HBM lactose content of $10.3-11.4 \mathrm{~g} / 100 \mathrm{kcal}$ (as the main source of carbohydrates) is also closely mimicked in IFs while HBM oligosaccharides (the third largest component after lactose and lipids, 0.8-3 g / $100 \mathrm{kcal}$ HBM) cannot be fully reproduced. Finally, while the lipid contents of both HBM and IFs are 5$6 \mathrm{~g} / 100 \mathrm{kcal}$ in average, lipid composition greatly differs as the lipid matrix of most IFs is exclusively made of a blend of vegetable oils instead of dairy fats. Only the addition of docosahexaenoic acid (DHA, 20-50 mg/100 kcal) belonging to long-chain polyunsaturated fatty acids (LC-PUFAs) of the $\omega 3$ family, is now mandatory in European IFs. However, the use of vegetable oils induces other major differences in the fat globule and triglycerides structure that may impact the developmental physiology of neonates (Le Huërou-Luron et al., 2010).

The present review aims to compare lipid composition of HBM, cow milk (CM) and IF, and to highlight recent findings about lipid structure and composition effects on neurodevelopment, protection against infections, gut barrier functions and metabolic health in infants.

\section{Compared lipid composition and milk fat globule structure of human breast milk, cow milk and IFs}

The metabolizable energy content of HBM and CM is approximately $65-70 \mathrm{kcal} / 100 \mathrm{~mL}$, one half being provided by fat. The estimated total fat intake of fully breast-fed infants is approximately $5.5 \mathrm{~kg}$ during the first six months of life (Koletzko et al., 2011). Lipids in HBM and CM represent on average $3.6 \mathrm{~g} / 100 \mathrm{~mL}$ with more than $97 \%$ as triglycerides (TAG), small amounts of mono- and diacylglycerides (MAG, DAG), around $1 \%$ of phospholipids and $0.5 \%$ of sterols, mostly cholesterol (Tab. 1) (Bourlieu et al., 2015). HBM and CM lipid composition are characterized by a large diversity of fatty acids (FAs) (over 400 FAs with variable chain lengths and unsaturations), a wide variability of LC-PUFAs, and a unique stereospecific structure with palmitic acid primarily esterified at the $s n-2$ position ( $70 \%$ in HBM and $45 \%$ in $\mathrm{CM})$ and unsaturated FAs mainly at the sn-1,3 positions (oleic acid is the major monounsaturated FA, $17-47 \%$ of milk total FAs). The HBM contains a lower percentage of saturated FAs, including short-chain FAs, compared to CM. It is noticeable that the energy and macronutrient contents of HBM and CM vary depending on the lactation period, the time of the day and also within feedings. In addition, HBM and CM lipid composition is greatly influenced by maternal diet (Lock and Bauman, 2004; Jensen, 2006; Innis, 2007; Delplanque et al., 2015).

The steady IF composition is designed to meet the nutrient requirements of infants for the whole first six months of life. IF lipid composition, quantitatively close to average mature HBM, greatly depends on the blend of the different fat sources used. IFs containing dairy fats were primarily used in the first part of the 20th century, but are nowadays very limited. Most IFs rather contain plant lipids, such as palm oil, coconut oil, sunflower oil or soy oil. Coconut oil provides short- and medium-chain FAs as do dairy lipids, and palm oil has, like dairy lipids, a high palmitic acid content. However, palmitic acid differs according to the lipid sources by the stereo-specific positioning of FAs on the glycerol molecule, with the higher percentage of esterification at the sn- 2 position in dairy lipids compared with palm oil. This position is of great nutritional importance as long-chain saturated FAs in the sn-2 position are more easily and efficiently digested and absorbed (Innis, 2011). Due to their content in plant oils, IFs usually contain more LC-PUFAs of the $\omega 3$ and $\omega 6$ families than HBM (for $\omega 3$ PUFA $11.6-26.0 \%$ of total FAs in HBM vs. 13.6-21.9\% of total FAs in IFs; for $\omega 6$ PUFA $0.85-3.57 \%$ of total FAs in HBM vs. $1.9-3.7 \%$ of total FAs in IFs). However, LA:ALA and ARA:DHA ratios are within the same range of values in IFs and HBM, i.e. from 3.5 to 12 and from 1.0 to 4.0, respectively (Delplanque et al., 2015).

Another important difference between HBM and IFs is the ultrastructure of the fat emulsion. HBM fat is organized under its native form into dispersed globules enveloped by a biological membrane called milk fat globule membrane (MFGM) resulting from the secretion of fat globules from the epithelial cells of the mammary gland. Fat globules are coated with three layers: an internal protein layer, an intermediate layer both consisting of phospholipids, and an external layer mainly consisting of high-molecular weight glycoproteins. HBM glycoproteins display branched oligosaccharide structure on their surface whereas oligosaccharides would be absent or present at a low level in CM. Milk fat globules (MFG) have a mean diameter around 3-5 $\mu \mathrm{m}$ but present a large range in size distribution $(0.1-15 \mu \mathrm{m})$ in both HBM and CM. In contrast, IF fat is dispersed in the micellar phase of the formula by homogenization of vegetable oils in the presence of dairy proteins. This process results in a stable micro-emulsion of vegetable lipids mainly stabilized by caseins in the form of small lipid droplets with an average diameter of less than $0.5 \mu \mathrm{m}$ without membrane coating (Bourlieu et al., 2017).

\section{Health benefits of MFGM supplemented IFs}

MFGM is highly structured and contains membranespecific proteins (mainly glycoproteins that represent $70 \%$ of MFGM dry matter), polar lipids (phospholipids and glycosphingolipids that represent $25 \%$ of MFGM dry matter), but also apolar lipids such as cholesterol $(2 \%$ of MFGM dry matter) and cerebrosides (3\% of MFGM dry matter) (Dewettinck et al., 2008). The proteome of HBM and CM MFGM includes 200 to 250 identified proteins 
Table 1. Compared human breast milk, cow milk and infant formula composition.

Adapted from (Malacarne et al., 2002; Brenna et al., 2007; Ballard and Morrow, 2013; Delplanque et al., 2015).

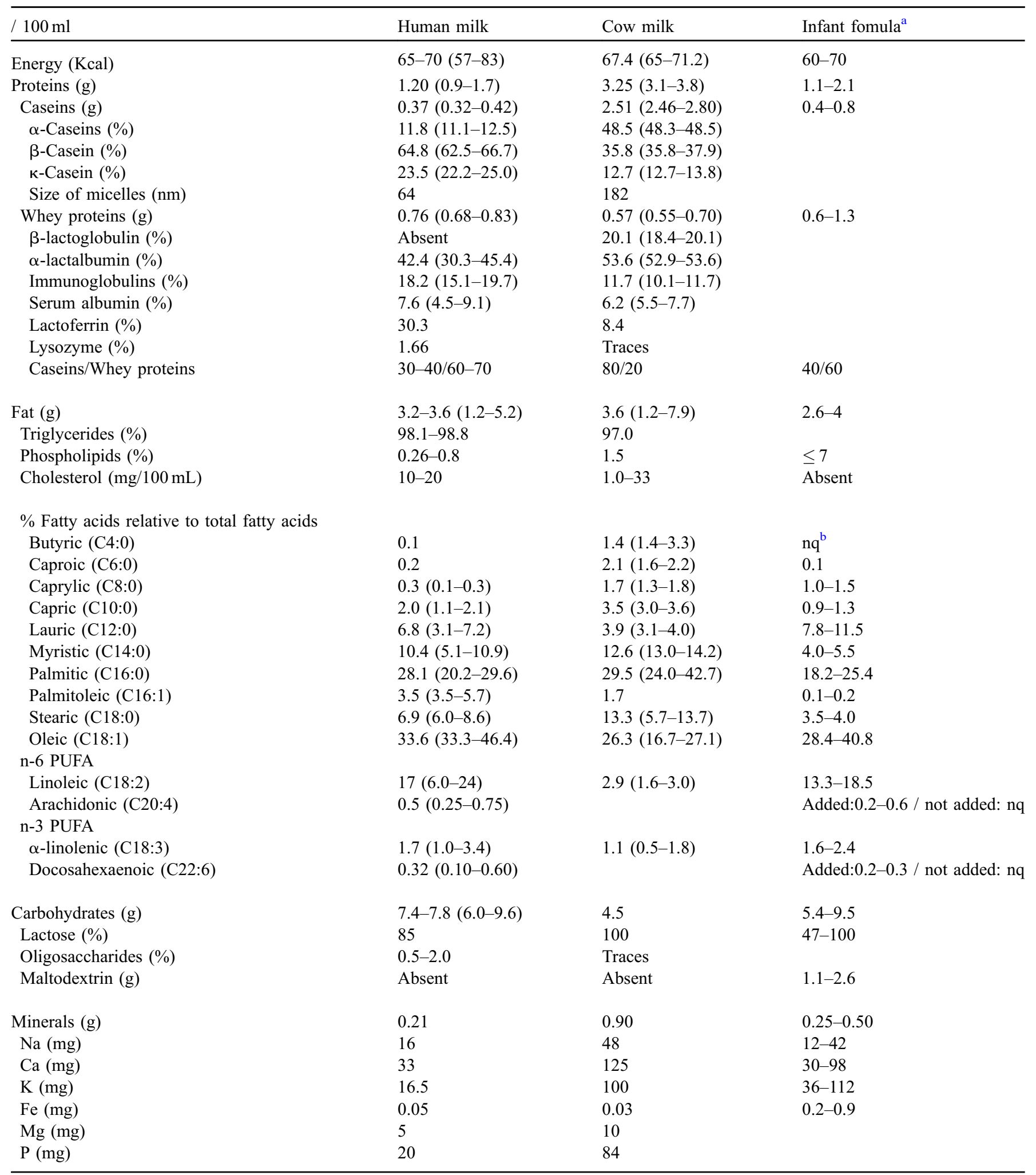

Mean value and, between brackets minimum-maximum values, reported in literature.

${ }^{a}$ Lipid composition provided in this table is that of an infant formula based of a blend of plant oils including palm oil and coconut oil, as an example of infant formula made with plant oils as lipid source.

${ }^{\mathrm{b}} \mathrm{Nq}$, non quantifiable amount $(<0.05 \%)$. 
(Hernell et al., 2016). Growing interest of supplementing IFs with MFGM comes not only from its individual components that have proven bioactivities, with reported impact on brain development and cognitive functions, immunity and gut physiology, but also from the benefits associated to the combination of these components and their structural organization. The persistence of MFGs in the upper intestine allows the discharge of bioactive components in the distal intestine, contributing to their physiological impacts. In the following section, health benefits of supplementing IFs with MFGM will be reviewed.

\subsection{MFGM improves brain development}

A large observational study ( $>17000$ healthy infants) has provided strong evidence for an advantage of breastfeeding compared to IF-feeding on infant cognitive development, suggesting that HBM components are important for an optimal neurodevelopment of infants (Kramer et al., 2008). Results of a randomized trial including $<2$ months of age infants fed a MFGM-supplemented, low-energy, low-protein experimental IF showed a positive association with neurocognitive development. At 12 months of age, the cognitive score (Bayley Scales of Infant and Toddler development tests) was significantly higher in the MFGM-supplemented experimental IF group than in the standard IF group but was not significantly different from that of breastfed infant group (Timby et al., $2014 a, b)$. Beneficial effects on emotional and behavioral regulation were also reported in preschool children consuming MFGM concentrate in chocolate formula milk for 4 months (Veereman-Wauters et al., 2012). Magnetic resonance imaging of piglet brain opened a new insight on underlying mechanisms. MFGM combined with prebiotics and lactoferrin induced differential localization in grey and white matter tissue concentrations suggesting an accelerated early postnatal brain development (Mudd et al., 2016). However, whether MFGM supplementation benefits result from the action of a single or a combination of bioactive components such as gangliosides, sphingomyelin, sialic acid, or cholesterol, is not known yet. Indeed, human neonates fed IF supplemented with gangliosides or sphingomyelin from milk displayed improved motor, neurobehavioural and cognitive development (Gurnida et al., 2012; Tanaka et al., 2013). In an animal study, supplementation with case in glycomacropeptide as a provider of sialic acid was associated with faster learning of difficult tasks and higher concentrations of protein-bound sialic acid in the frontal cortex and of learning-related genes in the hippocampus of piglets (Wang et al., 2007). It has also been reported that cholesterol played an important role in synaptic plasticity, learning and memory since rats receiving a diet supplemented with cholesterol displayed better performances in learning and memory than rats receiving a normal diet (Ya et al., 2013). Therefore, more studies have to be performed to unpack the mechanisms through which MFGM operates. Recent data in mice fed a diet mimicking more closely the lipid structure of breast milk (large lipid droplets coated with milk phospholipids) demonstrated improved performance in short-term memory tasks during adolescence and adulthood, suggesting that lipid structure would be also a relevant target to improve IF functionality (Schipper et al., 2016).

\subsection{MFGM prevents infection and improves gut barrier integrity in challenging conditions}

Formula-fed infants are more prone to ear, respiratory and gastrointestinal infections than breastfed ones during the first year of life. The first study performed with young children consuming MFGM-enriched complementary food reported a decreased number of days with fever in young European children aged 2.5 to 6 years ( 4 month distribution), without any impact on diarrhea, constipation and cough (VeeremanWauters et al., 2012). Timby et al. (2015) corroborated this MFGM preventive effect on infections in younger Swedish children recruited before 2 months of age and fed with MFGMsupplemented IF until 6 months of age. Fewer episodes of acute otitis media and lower antipyretic use during the intervention were reported among infants fed the MGFMsupplemented IF compared with infants fed a non-supplemented IF. As proposed by the authors, MFGM-embedded glycoproteins (such as butyrophilin, lactadherin, mucins, lactoferrin) and lipids (gangliosides) may participate in the defense against infections by preventing pathogen adhesion to epithelium (Sprong et al., 2012; Fuller et al., 2013).

The benefit of MFGM in reducing the prevalence of diarrhea is far less well-documented. Indeed in Peruvian infants aged 6 to 11 months, 6 month distribution of complementary food with protein provided as whey protein enriched with the MFGM-enriched protein fraction vs. an equal amount of skim milk protein, reduced the global prevalence of acute diarrhea (3.84 \% in the MFGM group $v s$. $4.37 \%$ in the control group, $P<0.05$ ) (Zavaleta et al., 2011). In contrast, a prospective trial in which 8 to 24 month Indian infants received daily $2 \mathrm{~g}$ of complex milk lipids containing 10 to 20-fold higher phospholipids than standard commercial IF did not demonstrate a preventing effect on rotavirus diarrhea prevalence (Poppitt et al., 2014). It is noticeable that the incidence of rotavirus infection was unexpectedly low in this trial, hampering the assessment of the supplementation efficacy. Similarly, MFGM-enriched milk was not associated with changes in diarrhea or abdominal discomfort scores in Belgian children (Veereman-Wauters et al., 2012). Finally the safety evaluation of standard IF and IF enriched with a protein-rich MFGM fraction or a lipid-rich MGFM fraction in a multicenter trial with French and Italian full-term neonates age $<14$ days did not reveal between-group differences in terms of diarrhea, intestinal discomfort, and ear, respiratory and gastrointestinal infections (Billeaud et al., 2014). A higher rate of eczema was evidenced in the group receiving IF enriched with a protein-rich MFGM fraction, though this negative effect has not been described ever since in other trials using the same MFGM fraction (Timby et al., 2014a, b). The few significant findings observed for prevention of diarrhea in human trials contrast with the beneficial impacts on gut epithelial barrier reported in animal studies. Indeed 10 day MFGM-supplemented formula feeding to rat pups from postnatal day 5 normalized delayed intestinal growth induced by standard IF feeding compared to suckling rats (Bhinder et al., 2017). Specifically MFGM restored intestinal villus and crypt architecture and maintained crypt cell proliferation and the number of goblet cells and Paneth cells involved in protective and antimicrobial activities. But MFGM-supplementation did not change FITC-dextran 
intestinal permeability, although it improved expression of tight junction proteins. Using neonatal piglets, we also evidenced MFGM-induced mucosal growth without any impact on epithelial permeability as measured in Ussing chambers (Le Huërou-Luron et al., 2018). Moreover, in challenging conditions against pathogenic bacteria such as Clostridium difficile or Listeria monocytogenes, MFGM were described as conferring protection, probably by stimulating mucin secretion and preventing adherence of pathogens to the intestinal mucosa in rats (Sprong et al., 2012; Bhinder et al., 2017). In weaned mice, providing a membrane-rich milk fat feed decreased the inflammatory response to a systemic LPS challenge and was associated with decreased gut permeability (Snow et al., 2011). These effects may be partly related to gangliosides that inhibited degradation of tight junction occludin during LPS-induced acute inflammation (Park et al., 2010). Therefore, a role of MFGM and its components in protecting the integrity of the intestinal barrier is only demonstrated using disease models, suggesting a protection of the gut barrier mainly in acute inflammatory conditions.

\subsection{MFGM and metabolic health}

No effect on infant growth (Timby et al., 2014a, b; Billeaud et al., 2014) and very few effects on metabolic parameters such as a higher cholesterol serum level (Timby et al., 2014a, b) or no difference in cholesterol level but a higher LDL concentration (Lukoyanova et al., 2017) were reported with MFGM supplementation. An IF containing large, phospholipid-coated lipid droplets was also found to support adequate growth in healthy Asian infants during the first 4 months of life as with a standard IF (Shek et al., 2017). Besides, recent animal studies highlight the importance of the structure of MFG on later adiposity and metabolism without any effect on growth. Indeed providing to mice pups IF with large vegetable fat droplets covered by milk phospholipids of MFGM origin (concept IF Nuturis ), resulting in particle size distribution and interfacial composition close to HBM (Gallier et al., 2015), reduced fat accumulation as well as fasting leptin, resistin, glucose and lipids in adults fed a western diet (Oosting et al., 2012). Both large droplet size and MFGM coating contributed to the observed protective effect against obesity in later life (Baars et al., 2016). The programming effect of MFG size would involve key regulators of metabolic activity such as decreased expression of PPAR $\gamma, \mathrm{CCAAT} / \mathrm{enhancer}$ binding protein and RXR in white adipose tissue in adulthood, and a reduced adipocyte hypertrophy (Oosting et al., 2014). The digestive behavior of these specific MFG is still questioned (Bourlieu et al., 2017).

Overall, the complexity of MFGM composition and structure, impacts many functions. However, not all MFGM protein and lipid components are commercially available. The reintroduction of bovine milk fat, which resembles that of HBM such as the presence of MFGM, similar w3 PUFA concentration, close TG content and a high percentage of esterification of palmitate at the sn-2 position, would be an alternative way to better mimic HBM-induced health benefits in infants and adulthood (Delplanque et al., 2015; Lonnerdal, 2016; Bourlieu et al., 2017).

\section{Benefits of bovine milk fat in IFs}

The addition of dairy lipids in IF modifies the structure of the fat emulsion and its composition in polar and apolar lipid fractions. Introducing fat from CM in IFs may also have consequences on the presence of potentially bioactive proteins (Li et al., 2014). An IF containing a mix of CM lipids and plant oils enabled a normal growth of healthy Italian newborns from inclusion (at $<3$ weeks of age) to the 4 subsequent months compared to control IF containing only plant oils as lipid sources, without any significant impact on gastrointestinal symptoms or infant behavior (Gianni et al., 2018). Benefits of the introduction of dairy lipids in IFs were observed in animal models. In a murine model with an early life LPS-induced brain inflammation, the partial replacement of vegetable lipids with dairy lipids had a protective effect on the adverse consequences of LPS exposure on neurogenesis and adult spatial memory (Dinel et al., 2016). In a neonatal piglet model fed IF from birth, the presence of dairy lipids in combination with MGFM changed the dynamic of dairy protein digestion compared to IF containing only vegetable lipids or vegetable lipids plus MFGM, with a higher resistance of casein and $\beta$-lactoglobulin to digestion (Le Huërou-Luron et al., 2018). This effect may be related to differences in emulsion interface composition between IFs (Macierzanka et al., 2009). Introduction of dairy lipids also resulted in modified luminal contents in the intestine, increasing $\beta$-casein peptides while decreasing lipids in jejunal digesta of pigs fed dairy lipids and MFGM-supplemented IF, compared to the ones fed exclusive vegetable lipid IF. In addition, intestinal contents of piglets fed dairy lipids and MFGM-supplemented IF displayed higher amounts of medium-chain saturated fatty acids, phosphatidylcholine and sphingomyelin. The addition of dairy lipids also accelerated the maturation of the intestinal immune system that was closer to the one observed in mother-fed piglets (Le Huërou-Luron et al., 2016). A follow-up of this study was recently performed by investigating long-term impacts of dairy lipids in IF on adult gut physiology. IF supplemented with dairy lipids had a beneficial impact on intestinal immune function. Indeed in adult pigs fed a dairy lipid-supplemented IF in infancy, pro-inflammatory cytokine (TNF $\alpha$ and IL-8) secretions of ileal explants in response to a LPS challenge was decreased compared to adult pigs early fed IF containing vegetable lipids (Lemaire et al., 2017). Therefore, the introduction of bovine fat in IFs may reduce the gap between breast-fed and IF-fed infant physiology and health, with a higher efficacy than the introduction of solely MFGM, as demonstrated in animal studies. It is noticeable that bovine fat contains a low fraction of MFGM that may account for $2-6 \%$ of the fat mass (Zheng et al., 2013).

More recently, the interaction between the lipid matrix and gut microbiota was questioned. Formula-feeding is usually associated with a higher bacterial richness and diversity and different taxonomic composition compared with breastfeeding. Supplementation of IF with MFGM-did not change oral microbiota species richness compared to standard IF fed infants and both formula-fed infants display higher species richness than breastfed infants at 4 months of age. However, differences still occurred at taxonomic levels (Timby et al., 2017a, b). Similarly, the composition of fecal microbiota 
differed between piglets fed IF containing dairy lipids and MFGM or IF containing vegetable lipids or mother-reared (Le Huërou-Luron et al., 2018).

\section{Conclusion}

Overall, numerous human studies have reported beneficial effects of MFGM supplementation on neurocognitive development and protection against infectious agents without deleterious impact on growth. Based on animal studies, benefits of introducing bovine MFGM and dairy lipids in IFs on gut digestion, physiology and protection against pathogens and inflammatory challenges have also been highlighted.

Lipids in breast milk are extremely complex and diverse, and their synergistic roles on health outcomes are not yet fully understood. Introducing dairy lipids including MFGM may be an important way to improve quality of IFs. However, more randomized controlled trials testing lipid functions must be performed to increase scientific-based knowledge and address safety concerns (Delplanque et al., 2015; Timby et al., 2017a, b). Another issue of using IFs supplemented with dairy lipids concerns the programming of adult health. Recent animal studies report promising effects but better understanding of underlying mechanisms must be achieved to reach optimal use of dairy lipids.

\section{References}

Baars A, Oosting A, Engels E, et al. 2016. Milk fat globule membrane coating of large lipid droplets in the diet of young mice prevents body fat accumulation in adulthood. Br J Nutr 115: 1930-1937.

Ballard O, Morrow AL. 2013. Human milk composition: nutrients and bioactive factors. Pediatr Clin North Am 60: 49-74.

Bhinder G, Allaire JM, Garcia C, et al. 2017. Milk fat globule membrane supplementation in formula modulates the neonatal gut microbiome and normalizes intestinal development. Sci Rep 7: 45274.

Billeaud C, Puccio G, Saliba E, et al. 2014. Safety and tolerance evaluation of milk fat globule membrane-enriched infant formulas: a randomized controlled multicenter non-inferiority trial in healthy term infants. Clin Med Insight Pediatr 8: 51-60.

Bourlieu C, Bouzerzour K, Ferret-Bernard S, et al. 2015. Infant formula interface and fat source impact on neonatal digestion and gut microbiota. European J Lipid Sci Tech 117: 1500-1512.

Bourlieu C, Deglaire A, De Oliveira SC, et al. 2017. Towards infant formula biomimetic of human milk structure and digestive behaviour. OCL 24: D206.

Brenna JT, Varamini B, Jensen RG, Diersen-Schade DA, Boettcher JA, Arterburn LM. 2007. Docosahexaenoic and arachidonic acid concentrations in human breast milk worldwide. Am J Clin Nutr 85: $1457-1464$

Delplanque B, Gibson R, Koletzko B, Lapillonne A, Strandvik B. 2015. Lipid quality in infant nutrition: current knowledge and future opportunities. J Pediatr Gastroenterol Nutr 61: 8-17.

Dewettinck K, Rombaut R, Thienpont N, Le TT, Messens K, Van Camp J. 2008. Nutritional and technological aspects of milk fat globule membrane material. Int Dairy J 18: 436-457.

Dinel AL, Rey C, Baudry C, et al. 2016. Enriched dairy fat matrix diet prevents early life lipopolysaccharide-induced spatial memory impairment at adulthood. Prostaglandins Leukot Essent Fatty Acids 113: 9-18.
Fuller KL, Kuhlenschmidt TB, Kuhlenschmidt MS, Jimenez-Flores R, Donovan SM. 2013. Milk fat globule membrane isolated from buttermilk or whey cream and their lipid components inhibit infectivity of rotavirus in vitro. J Dairy Sci 96: 3488-3497.

Gallier S, Vocking K, Post JA, et al. 2015. A novel infant milk formula concept: mimicking the human milk fat globule structure. Colloids Surf B Biointerfaces 136: 329-339.

Gianni ML, Roggero P, Baudry C, Fressange-Mazda C, Le Ruyet P, Mosca F. 2018. No effect of adding dairy lipids or long chain polyunsaturated fatty acids on formula tolerance and growth in full term infants: a randomized controlled trial. BMC Pediatr 18 : 10.

Gurnida DA, Rowan AM, Idjradinata P, Muchtadi D, Sekarwana N. 2012. Association of complex lipids containing gangliosides with cognitive development of 6-month-old infants. Early Hum Dev 88: 595-601.

Hernell O, Timby N, Domellof M, Lonnerdal B. 2016. Clinical benefits of milk fat globule membranes for infants and children. $J$ Pediatr 173: S60-65.

Innis SM. 2007. Human milk: maternal dietary lipids and infant development. Proc Nutr Soc 66: 397-404.

Innis SM. 2011. Dietary triacylglycerol structure and its role in infant nutrition. Adv Nutr 2: 275-283.

Jensen CL. 2006. Effects of n-3 fatty acids during pregnancy and lactation. Am J Clin Nutr 83: 1452S-1457S.

Koletzko B, Von Kries R, Closa R, et al. 2009. Lower protein in infant formula is associated with lower weight up to age 2 y: a randomized clinical trial. Am J Clin Nutr 89: 1836-1845.

Koletzko B, Agostoni C, Bergmann R, Ritzenthaler K, Shamir R. 2011. Physiological aspects of human milk lipids and implications for infant feeding: a workshop report. Acta Paediatr 100: 1405-1415.

Kramer MS, Aboud F, Mironova E, et al. 2008. Breastfeeding and child cognitive development: new evidence from a large randomized trial. Arch Gen Psychiatr 65: 578-584.

Lemaire M, Boudry G, Ferret-Bernard S, et al. 2017. Addition of dairy lipids and probiotic Lactobacillus fermentum CECT 5716 in infant formula programs gut microbiota, epithelial permeability, immunity and GLP-1 secretion in adult minipigs. In: Abstracts of the 50th Annual Meeting of the European Society for Paediatric Gastroenterology, Hepatology and Nutrition, Prague.

Le Huërou-Luron I, Blat S, Boudry G. 2010. Breast- v. formulafeeding: impacts on the digestive tract and immediate and longterm health effects. Nutr Res Rev 23: 23-36.

Le Huërou-Luron I, Bouzerzour K, Ferret-Bernard S, et al. 2018. A mixture of milk and vegetable lipids in infant formula changes gut digestion, mucosal immunity and microbiota composition in neonatal piglets. European J Nutr 57: 463-476.

Li Y, Jensen ML, Chatterton DE, et al. 2014. Raw bovine milk improves gut responses to feeding relative to infant formula in preterm piglets. Am J Physiol Gastrointest Liver Physiol 306: G81-90.

Lock AL, Bauman DE. 2004. Modifying milk fat composition of dairy cows to enhance fatty acids beneficial to human health. Lipids 39: 1197-1206.

Lonnerdal B. 2016. Bioactive proteins in human milk: health, nutrition, and implications for infant formulas. Journal Pediatr 173: S4-9.

Lukoyanova O, Borovik T, Bushueva, et al. 2017. The lipid metabolism in infants fed formula supplemented with bovine milk fat and bovine milk fat globule membranes. In: Abstracts of the 50th Annual Meeting of the European Society for Paediatric Gastroenterology, Hepatology and Nutrition; Prague. 
Macierzanka A, Sancho AI, Mills ENC, Rigby NM, Mackie AR. 2009. Emulsification alters simulated gastrointestinal proteolysis of $\beta$-casein and $\beta$-lactoglobulin. Soft Matter 5: 538-550.

Malacarne M, Martuzzi F, Summer A, Mariani P. 2002. Protein and fat composition of mare's milk: some nutritional remarks with reference to human and cow's milk. Int Dairy J 12: 869-877.

Mudd AT, Alexander LS, Berding K et al., 2016. Dietary prebiotics, milk fat globule membrane, and lactoferrin affects structural neurodevelopment in the young piglet. Front Pediatr 4: 4.

Oosting A, Kegler D, Wopereis HJ et al., 2012. Size and phospholipid coating of lipid droplets in the diet of young mice modify body fat accumulation in adulthood. Pediatr Res 72: 362-369.

Oosting A, Van Vlies N, Kegler D et al., 2014. Effect of dietary lipid structure in early postnatal life on mouse adipose tissue development and function in adulthood. Br J Nutr 111: 215-226.

Park EJ, Thomson AB, Clandinin MT. 2010. Protection of intestinal occludin tight junction protein by dietary gangliosides in lipopolysaccharide-induced acute inflammation. J Pediatr Gastroenterol Nutr 50: 321-328.

Poppitt SD, Mcgregor RA, Wiessing KR et al., 2014. Bovine complex milk lipid containing gangliosides for prevention of rotavirus infection and diarrhoea in northern Indian infants. $J$ Pediatr Gastroenterol Nutr 59: 167-171.

Schipper L, Van Dijk G, Broersen LM et al., 2016. A postnatal diet containing phospholipids, processed to yield large, phospholipidcoated lipid droplets, affects specific cognitive behaviors in healthy male mice. J Nutr 146: 1155-1161.

Shek L, Winokan A, Abrahamse-Berkeveld et al. 2017. An innovative infant milk formula with large, phospholipid-coated lipid droplets supports an adequate growth and is well-tolerated in healthy, term Asian infants. In: Abstracts of the 4th International Conference on Nutrition \& Growth; Amsterdam.

Snow DR, Ward RE, Olsen A, Jimenez-Flores R, Hintze KJ. 2011. Membrane-rich milk fat diet provides protection against gastrointestinal leakiness in mice treated with lipopolysaccharide. J Dairy Sci 94: 2201-2212.

Sprong RC, Hulstein MF, Lambers TT, Van Der Meer R. 2012. Sweet buttermilk intake reduces colonisation and translocation of Listeria monocytogenes in rats by inhibiting mucosal pathogen adherence. Br J Nutr 108: 2026-2033.

Tanaka K, Hosozawa M, Kudo N et al., 2013. The pilot study: sphingomyelin-fortified milk has a positive association with the neurobehavioural development of very low birth weight infants during infancy, randomized control trial. Brain Dev 35: 45-52.

Timby N, Domellof E, Hernell O, Lonnerdal B, Domellof M. 2014a. Neurodevelopment, nutrition, and growth until 12 mo of age in infants fed a low-energy, low-protein formula supplemented with bovine milk fat globule membranes: a randomized controlled trial. Am J Clin Nutr 99: 860-868.

Timby N, Lonnerdal B, Hernell O, Domellof M. 2014b. Cardiovascular risk markers until 12 mo of age in infants fed a formula supplemented with bovine milk fat globule membranes. Pediatr Res 76: 394-400.

Timby N, Hernell O, Vaarala O, Melin M, Lonnerdal B, Domellof M. 2015. Infections in infants fed formula supplemented with bovine milk fat globule membranes. J Pediatr Gastroenterol Nutr 60: 384-389.

Timby N, Domellof M, Holgerson PL et al., 2017a. Oral microbiota in infants fed a formula supplemented with bovine milk fat globule membranes - a randomized controlled trial. PloS one 12: e0169831.

Timby N, Domellof M, Lonnerdal B, Hernell O. 2017b. supplementation of infant formula with bovine milk fat globule membranes. Adv Nutr 8: 351-355.

Veereman-Wauters G, Staelens S, Rombaut R et al., 2012. Milk fat globule membrane (INPULSE) enriched formula milk decreases febrile episodes and may improve behavioral regulation in young children. Nutrition 28: 749-752.

Wang B, Yu B, Karim M et al., 2007. Dietary sialic acid supplementation improves learning and memory in piglets1-3. Am J Clin Nutr 85: 561-569.

Weber M, Grote V, Closa-Monasterolo R et al., 2014. Lower protein content in infant formula reduces BMI and obesity risk at school age: follow-up of a randomized trial. Am JClin Nutr 99: 1041-1051.

Ya BL, Liu WY, Ge F, Zhang YX, Zhu BL, Bai B. 2013. Dietary cholesterol alters memory and synaptic structural plasticity in young rat brain. Neurol Sci 34: 1355-1365.

Zavaleta N, Kvistgaard AS, Graverholt G et al., 2011. Efficacy of an MFGM-enriched complementary food in diarrhea, anemia, and micronutrient status in infants. J Pediatr Gastroenterol Nutr 53: 561-568.

Zheng H, Jimenez-Flores R, Everett DW. 2013. Bovine milk fat globule membrane proteins are affected by centrifugal washing processes. J Agric Food Chem 61: 8403-8411.

Cite this article as: Huërou-Luron IL, Lemaire M, Blat S. 2018. Health benefits of dairy lipids and MFGM in infant formula. OCL 25(3): D306. 